\title{
Anatomical aspects of the ginger flower Etlingera elatior (Jack.) RM Smith, acclimatization with the usage of different nutritive solutions
}

\author{
Jessé Marques da Silva Júnior Pavão'* \\ Selenobaldo Alexinaldo Cabral Sant'Anna', Thomé Rodrigues de Pontes Bomfim', \\ Aldenir Feitosa dos Santos', João Gomes da Costa', Mayara Andrade Souza', Thiago José Matos Rocha' \\ ${ }^{1}$ Postgraduate Program in Environmental Systems Analysis - Centro Universitário Cesmac - Maceió - Alagoas- Brazil, ${ }^{2}$ Program in \\ Botany - Federal University of Lavras - Lavras - Minas Gerais - Brazil
}

\section{A B S TR A C T}

The Ginger flower, Etlingera elatior (Jack.) RM Smith (also known as torch ginger, ginger flower, red ginger lily, torch lily, wild ginger), belonging to the Zingiberaceae family, stands out with one of the main ornamental tropical species. The objectives of the present study were to establish an acclimatization methodology for in vitro cultivated cane seedlings, and to compare the internal structure of leaves of seedlings submitted to different nutrient solutions. The seedlings from the in vitro culture were transplanted into trays with inert substrate (expanded vermiculite $+10 \%$ sand), where they remained in a growth room with controlled temperature of $25 \pm 2{ }^{\circ} \mathrm{C}$ and photon irradiance of $67 \mu \mathrm{m} \mathrm{m}^{-2} \mathrm{~s}^{-1}$. Moisture control was carried out by using a transparent plastic bag, which was removed after 15 days and shortly thereafter, the experiments were started with the use of nutritive solutions MS (Murashige \& Skoog), BJ (Bolle-Jones) and HO (Hoagland \& Arnon) at $35 \%$ of their ionic strength. For the anatomical study, transverse and paradermal sections were realized in the foliar laminae of seedlings in vitro, in period of acclimatization and in plants already established. The in vitro seedlings showed survival at $100 \%$ when transferred to the ex vitro condition. In the cross sections and leaf parser, anatomical differences between the seedlings of the different environments were observed. The abaxial and adaxial epidermis presented significant differences in the environments in which the seedlings developed, showing themselves to be thicker as the acclimatization period increased. The thickness averages of the palisade parenchyma did not differ statistically in the acclimatization periods and in the different nutrient solutions tested. On the other hand, those ones of the spongy parenchyma's presented significant differences in relation to the nutrient solutions tested, evidencing in all evaluations the MS solution, which contributed the most to the development of the internal structures of the leaf (spongy parenchyma and central vascular cylinder). The highest stomatal density was observed in seedlings developed in vitro (250 stomata per mm $\left.{ }^{2}\right)$ when compared to those ones already acclimatized or even to that one of field, 200 and 190 stomata per $\mathrm{mm}^{2}$ respectively. The stomata of the Ginger flower leaves developed in vitro presented with polar and equatorial diameters greater than the stomata of leaves already acclimatized and as well as of field.

Keywords: Anatomical changes; Ex vitro culture; In vitro culture; Tropical ornamental plant

\section{INTRODUCTION}

In Brazil, it stands out as an economically growing activity, the productive sector of flowers and plants, which has been consolidating itself into more relevant positions in the national agribusiness. In addition to adding high potential for future expansion, it has generated employment and income for micro and small producers across the country, especially rural women and thus, sustaining favorable economic performance, despite the context of the economic crisis and financial impact that has affected the country in recent years (Junqueira, Peetz, 2014; Junqueira, Peetz, 2017).

Per capita consumption of flowers and ornamental plants in Europe per year is $\$ 60.0$ and in the United States the average is $\$ 37.0$ per year - with higher sales concentrations during the vacation period. Brazil, on the other hand, still has an average of much below (US\$ 7.5 per year) when compared to the countries mentioned (Anacleto et al., 2017).

\footnotetext{
${ }^{*}$ Corresponding author:

Jessé Marques da Silva Júnior Pavão, Postgraduate Program in Environmental Systems Analysis - Centro Universitário Cesmac - Maceió Alagoas- Brazil.E-mail: jesse.marques@cesmac.edu.br
}

Received: 01 April 2019; Accepted: 11 September 2019 
Among the Zingiberaceae, which are tropical ornamental species, the Ginger flower [Etlingera elatior (Jack.) RM Smith], a native plant to Malaysia, stands out. The family includes several species with applications in horticulture, particularly for their use in cooking, medicinal, ornamentation and landscaping and that has been cultivated for many years in Brazil, with great potentiality, mainly as a cut flower. Their seedlings are usually obtained by division of clumps, or by seeds; however, this practice may lead to several problems during cultivation, such as low germination percentage and disease spread (Bezerra; Loges, 2005; Umemoto et al., 2012, Silva et al., 2017).

Specifically for the cultivation of Ginger flower seedlings obtained from in vitro cultivation using nutrient solutions for acclimatization, there are few studies that indicate the nutritive solution for the establishment of these plants outside the glass, which may promote the necessary anatomical changes as greater lignification of the tissues, which are the decisive aspects in the acclimatization capacity of the aforementioned species, exposed to different environmental conditions. (Hanba et al., 2002, Schluter et al., 2003, Silva et al., 2017). Among the solutions are: Hoagland \& Arnon (HO) (Neves et al., 2005), Bolle-Jones (BJ) (Santos et al., 2005) e Murashige \& Skoog (MS) (Neto et al., 2004).

This stage, however, may become a limiting factor in the micropropagation process (Grattapaglia; Machado, 1998). Therefore, for a better response in acclimatization, high relative humidity, low irradiance and mild temperature must be provided (Debergh, 1991, Yunus et al., 2012). In addition, roots produced in vitro are poorly functional, reason why it should be replaced as soon as possible, which will only occur while maintaining the plant with low transpiration. On the other hand, George (1996) observed that roots formed in vitro do not develop adequately for many micropropagated species.

According to Silva et al. (2014), environmental changes in in vitro cultivation can lead to tissue changes, such as roots and leaves, which are essential tissues for the survival of a plant. Thus, these organs formed in these conditions are insufficient regarding the internal maturity of tissues that are considered essential and decisive in the acclimatization and survival processes of these plants when exposed to high conditions relative humidity and low atmosphere in gases (Hanba et al., 2002, Schluter et al., 2003).

Leaf morphological aspects are key factors for translating environmental conditions and promoting the adaptation of in vitro or ex vitro plants to the new environment, but techniques before transplantation are applied to promote a pre-acclimatization even with plants in vitro (Dunbar-Co et al. 2009, Guan et al. 2011). These adaptations strongly influence internal structural changes in leaf tissues so that they become functional and can help the plant have autonomy. If these adaptations occur late or do not occur, serious implications affecting growth due to interference in photosynthetic and metabolic capacity can be proven through plant death (Vendramini et al. 2002; Pandey et al. 2009). To understand the internal and external changes of plants due to the growth environment, an area of botany, ecological anatomy, is responsible for evidencing and explaining changes such as: cuticular thickening and parenchymatic tissues, production of secondary metabolites that function as a biofilm reflecting excess radiation, stomata below the epidermis level, which contribute to the survival of these plants in adverse environmental conditions that require plasticity of these plants (Haworth and McElwain 2008; Mill and Stark Schilling 2009).

According to Luz et al. (2012), the leaf surface is one of the first regions of the leaf to react to the in vitro environment because in these conditions of high humidity, and low concentration of gases, the thickening of the epidermis is severely affected resembling a plant of aquatic environment, therefore, interferes with wax deposits as well as in some cases may alter the positioning and shape of stomata. As the main consequence of non-deposition of waxes and other elements in the epidermis, excessive water losses occur by sweating.

Changes in the cultivation environment can cause stress and compromise the vital functions of plants in the new environment, thus procedures for transferring plants from in vitro to ex vitro implies offering the plant still in vitro conditions for acclimatization process will succeed. During acclimatization the plant is in a critical period because the stomata are poorly functional, the cuticle is slender and the photosynthetic metabolism is little expressive. It is in this period that intense changes are observed whether they are anatomical, morphological, physiological and photosynthetic. These factors, crucial to the success of micropropagation as a technique for the spread of largescale plants (Guan et al. 2008, Van Huylenbroeck et al. 1998, Pospíśilová et al. 1999, Lamhamedi et al. 2003).

For the authors Brained and Fucchigami (1981), acclimatization of plants from the in vitro culture is one of the stages with greater risk of losses, because the plants are sensitive and tender; therefore, they do not develop the cuticle, resulting in high transpiration, and their cell wall does not present sufficient rigidity for sustaining; the leaves are thin and show lower photosynthetic rates, which causes stress in plants when transferred to the ex vitro environment. Besides, it is worth noting that an expressive number of plant species cultivated in vitro does not survive when transferred from those conditions to a greenhouse or field environment (Hararika, 2003). 
According to Campostrini and Otoni (1996) and Amancio et al. (1996) in micropropagated plants, especially in the traditional in vitro culture, there is a difficulty of transition from the heterotrophic mechanism to the photoautotrophic one, due to the anatomical, physiological, and epigenetic changes induced by in vitro conditions.

In this way, acclimatization represents for some species a limiting factor in the production, due to the high mortality rates, low growth rate and lack of uniformity of the micropropagated seedlings (Hazarika, 2006, Silva et al., 2011, Lima-Brito et al., 2016).

Therefore, conducting research that allows a better understanding of the main factors responsible for controlling excessive sweating of micropropagated plants, especially after the removal of plants from in vitro grown plants, is an interesting way to improve and/or develop more efficient transplant and acclimatization protocols.

Considering that the Ginger flower is a species that is not yet widespread and the lack of literature on the evolution of the leaf anatomy during the acclimatization process aided by the use of nutrient solutions, the present work had as objectives to establish a methodology for acclimatization for the seedlings cultivated in vitro, as well as to analyze the evolution of the foliar anatomy during acclimatization, using different nutrient solutions.

\section{MATERIALS AND METHODS}

The work was carried out at the Plant Tissue Culture Laboratory of the Department of Biology, Plant Physiology and Laboratory of Anatomy, Department of Biology, University Federal of Lavras, Lavras, State of Minas Gerais, Brazil.

\section{Plant material and culture conditions}

Micropropagated seedlings of var. Red Torch about $8 \mathrm{~cm}$ in length were used. The seedlings were obtained by in vitro rooting and stretching of axillary shoots in basal DM medium (Murashige e Skoog, 1962), plus 3 mg.L.-1 BAP (6-benzylaminopurine), $6 \mathrm{gL}^{-1}$ agar and $\mathrm{pH} 5.8 \pm 0.1$. For the cultivation, test tubes containing $10 \mathrm{~mL}$ of medium with only one bud per tube were used, sealed with clear plastic film and kept in a growth room under photon irradiance of $70 \mu \mathrm{m} \mathrm{m}^{-2} \mathrm{~s}^{-1}$, from lamps Philips TDL, in a photoperiod of 16 hours and a temperature of $25 \pm 2^{\circ} \mathrm{C}$.

\section{Ex vitro acclimatization}

Seedlings obtained by means of micropropagation with 90 days of age were transferred directly to trays containing substrate vermiculite $+10 \%$ of sand and surrounded by a with transparent plastic bag, as a small greenhouse (Fig. 1) in order to preserve the relative humidity and thus the seedlings were kept for 15 days. The tray was maintained in a growth room at a controlled temperature of $25 \pm 2^{\circ}$ $\mathrm{C}$ and photon irradiance of $70 \mu \mathrm{m} \mathrm{m}^{-2} \mathrm{~s}^{-1}$.

After 15 days, the experiments started with the use of three nutrient solutions: MS Murashige \& Skoog, (1962), Bolle \& Jones (1954) and Hoagland \& Arnon (1950) at 35\% ionic strength, irrigating these seedlings with $20 \mathrm{ml}$ per cell once a week. Each treatment consisted of 20 seedlings.

During the 60 days of acclimatization, 4 assessments were performed to verify the modifications in the foliar tissues as a result of the in vitro environment transfer to the ex vitro one. The density of stomata (number of stomata per $\mathrm{mm}^{2}$ ), polar and equatorial diameter of stomata $(\mu \mathrm{m})$, thickness of palisade parenchyma $(\mu \mathrm{m})$, lacunar parenchyma $(\mu \mathrm{m})$, abaxial and adaxial epidermis $(\mu \mathrm{m})$ and diameter of the central beam $(\mu \mathrm{m})$.

\section{Anatomical studies}

Anatomical assessments were carried out by means of observations made in parathermal sections (from the adaxial side), obtained by the free hand, using a stainless steel blade. To obtain the sections, the middle third of the second expanded leaf (apex-base direction), collected from different plants of each treatment and previously fixed in F.A. $A_{70}$ (formaldehyde, acetic acid and ethyl alcohol) (Johansen, 1940) was used for 48 hours and preserved in $70 \%(\mathrm{v} / \mathrm{v})$ ethyl alcohol. As for the preparation, the

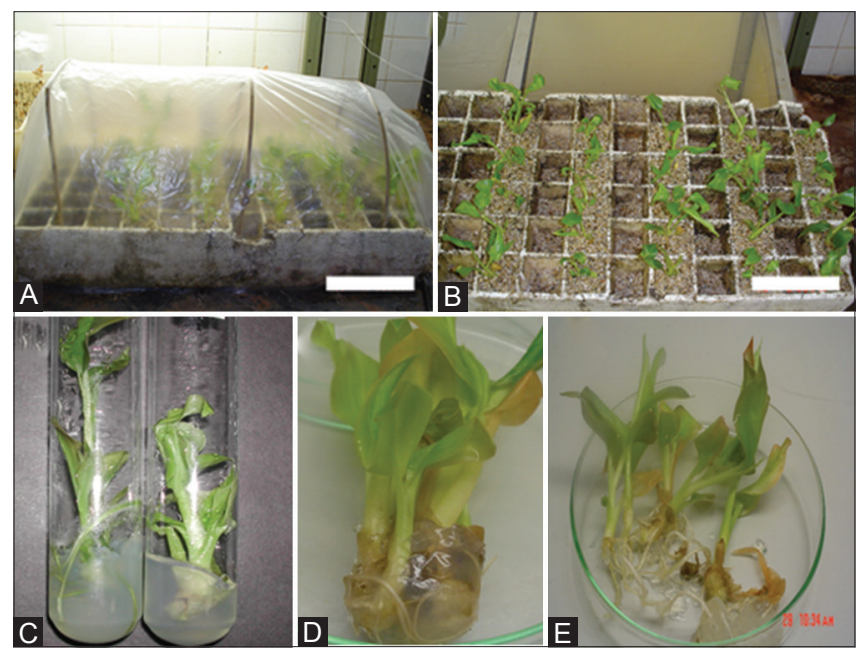

Fig 1. Process of acclimatization of seedlings of Etlingera elatiorvar. Red Torch (Ginger flower). (A) Mini- greenhouse adapted for acclimatization. Condition room acclimatization: photon irradiance $70 \mu \mathrm{mol} \mathrm{m}^{-2} \mathrm{~s}^{-1}$, from Gro-lux lamps, maximum temperature $31^{\circ} \mathrm{C}$ and minimum temperature $22{ }^{\circ} \mathrm{C}$. Relative humidity inside the greenhouse $95 \%$ and outside $65 \%$ and 16-hour photoperiod. B) Ginger flower seedlings on a tray with vermiculite $+10 \%$ sand. (C) Ginger flower seedlings in vitro. (D) Ginger flower seedlings ex vitro. (E) Ginger flower seedlings peaked. Fig A and $\mathrm{B}$, bars $-20 \mathrm{~cm}$. Fig $\mathrm{C}-\mathrm{D}$, bars $-10 \mathrm{~cm}$. 
sections were first clarified in sodium hypochlorite solution $(50 \% \mathrm{v} / \mathrm{v})$, submitted to triple washing in distilled water, stained with $1 \%$ safranine and mounted on slides using glycerinated water $(50 \% \mathrm{v} / \mathrm{v})$.

From these sections the analyzed variables were: stomatal density (number of stomata per $\mathrm{mm}^{2}$ ), polar and equatorial diameters of stomata.

The traverse sections were used to measure the thickness of the epidermis (adaxial and abaxial) and the palisade and lacunar parenchyma. For this purpose, 5 leaves with 4 sections evaluated per leaf (repetition) were used, making a total of 20 observations for the stomatal density variables, and 6 leaves with 4 sections evaluated for the polar (SD) and equatorial (SD) diameters and the DP/SD relation, in a total of 24 observations. The same number of repetitions was used for cross sections. All analyzed variables were obtained through measurements performed in the Sigma Scan Pro $5^{\circledR}$ program.

\section{Description of treatments}

The treatments consisted of four types of leaves, as described: T1 - leaves of plants at the end of the in vitro rooting phase; T2 - persistent leaves (formed in vitro) of plants with 30 days of acclimatization; T3 - new leaves formed ex vitro of plants with 45 days of acclimatization (transition leaves); T4 - new leaves of plants with 60 days of acclimatization. For entire control of the leaves of the treatments (T2) and (T4), different color ribbon coding was carried out.

\section{Experimental design and statistical analysis}

For the anatomy experiment, a completely randomized design (DIC) was used, with five replications. Data analysis was performed using the Sisvar software (Ferreira, 2015) with the use of the Scott-Knott test $(\mathrm{P}<0.05)$.

\section{RESULTS AND DISCUSSION}

\section{Ex vitro acclimatization}

For the anatomy experiment, a completely randomized design (DIC) was used, with five replications. Data analysis was performed using the Sisvar software (Ferreira, 2015) using the Scott-Knott test $(\mathrm{P}<0.05)$.

The number of surviving plants when three nutrient solutions are used was $100 \%$, that is, all the nutrient solutions tested, together with the substrate, were efficient in providing a favorable environment for the growth of emperor wand after 60 days (Fig. $1 \mathrm{~A}$ and B).

Similar results were found by Bosa et al., (2003), acclimatizing Baby's Breath (Gypsophilapaniculata) seedlings, which is an ornamental species, with the use of vermiculite and Bolle-Jones solution (1954), survival rates were obtained between 90 to $98 \%$. According to Maciel et al., (2000) evaluating the acclimatization of violet plants (Saintpaulia ionantha Wendl.). These authors found survival at $100 \%$ of the plants, by using the same substrate utilized in this work.

In growth room conditions (in vitro), the central rib of the Ginger flower leaves presents a small degree of tissues differentiation, especially with respect to the vascular ones (Fig. 2A); otherwise, in the mesophyll cells the axial epidermis appears uniserial, as well as the abaxial one (Fig. 2B), and the stomata have an oval shape (Fig. 2C) owing to the high percentage of relative humidity inside the glass, so leaving them open.

In comparison, the Ginger flower leaves, ex vitro, presented a dorsiventral and hyposomatic organization, characteristic of the species. In general sight of the central vein, the vascular system is well developed, consisting of collateral beams numbered 8 to 10 , and the formation of accessory beams is observed (Fig. 2D). The mesophyll is represented by one or two layers of palisade parenchyma, juxtaposed elongated cells and lacunated parenchyma cells, loosely arranged, in the number of 5 to 6 layers and few intercellular spaces; the bisserial adaxial epidermis is observed, while the abaxial remains uniserial, with cells of variable shape

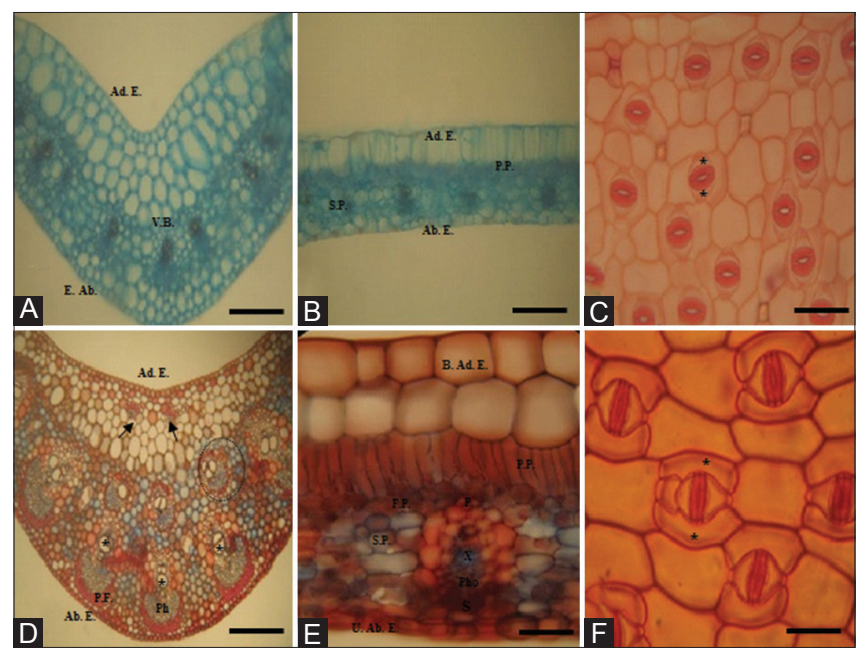

Fig 2. Cross-sections obtained from leaf blade of Etlingera elatior var. red Torch in vitro and acclimatized. A. central vein of plants in vitro. B. Mesophyll of plants in vitro. C. Parathermal section of plants in vitro. D. Central vein of acclimatized plants. E. Mesophyll of acclimatized plants. F. Parathermal section of acclimatized plants. Ad. E.- Adaxial Epidermis; P.P.-Palisade Parenchyma; P.-Pericycle; X.-Xylem; Pho.Phloem; B. Ad. E.- Bisserial Adaxial Epidermis; S.-Sclerenchyma; S.P.Spongy Parenchyma; F.P.-Fundamental Parenchyma; Ab. E.- Abaxial Epidermis; U. Ab. E. Unstratified Abaxial Epidermis.Arrows - Accessory bundles. Circular area - Closed collateral vascular bundle. Figures A, B, C and D 10x Bars -50 $\mu \mathrm{m}$; E and F 40x - Bars - $20 \mu \mathrm{m}$. Asterisk (C) Guards cells. Asterisk (F) Subsidiary cells. 
and dimensions, being the largest dimensions observed in the adaxial face. (Fig. 2E). In a paradermal section, it is seen that the stomata change in shape and begin to assume an ellipsoid shape, which keeps them closed, preventing them from losing the water inside the leaves, thus avoiding sweating.

In Fig. 2, the cross-section of the leaflet of in vitro seedlings, the tissues are little differentiated in relation to the $e x$ vitro plants. It is noted that the median vein has around 3 collateral vascular bundles, not evidence accessory bundles. Ex vitro, the plant has 2 accessory bundles and 8 to 10 vascular collateral bundles. In vitro, the tissue organization follows the patterns observed in ex vitro, such as the dorsiventral anatomy presenting palisade parenchyma in the upper face of the lamina (adaxial) and spongy parenchyma in the inferior (abaxial) face and are hypoestomatic.

According to Menezes et al., (2003), in species with dorsiventral mesophyll, the great majority of chloroplasts are found in cells of the palisade parenchyma. By reason of their shape and the arrangement of these cells, chloroplasts can be arranged parallel to cell walls, increasing photosynthetic efficiency.

In transversal section of the leaf blade, variations were observed in the epidermis thickness on the adaxial and abaxial surfaces (Fig. 3). For the different environments (both in vitro and exvitro), the epidermis is thicker in exvitro conditions. The mean leaf thickness was higher in plants also cultivated in the field when compared to plants grown in vitro, thus accompanying the thickness of the palisade and spongy parenchyma (Fig. 3).

Due to the use of the three nutrient solutions tested, MS (Murashige \& Skoog, 1962), HO (Hoagland \& Arnon, 1950) e BJ (Bolle-Jones, 1954) there were significant differences in the thickness of the tissues assessed (lacunar parenchyma and central vascular bundle) at 30 days of acclimatization (Fig. 4).

As for the epidermis, the adaxial started the cell division process from the 30 days of acclimatization (Fig. 4 D, E and F) independent of the nutrient solution used and the abaxial as mono stratified, covered by the cuticle. The thickening of the cuticle is a characteristic that gives the plants grown in the natural environment an extra protection against the action of solar radiation, by the reflection of the solar rays, avoiding an overheating of the cytoplasm of the mesophyll cells. (Alquini et al., 2003).

For the palisade parenchyma, there were no significant differences regarding the use of the three nutrient solutions (Fig. 5).

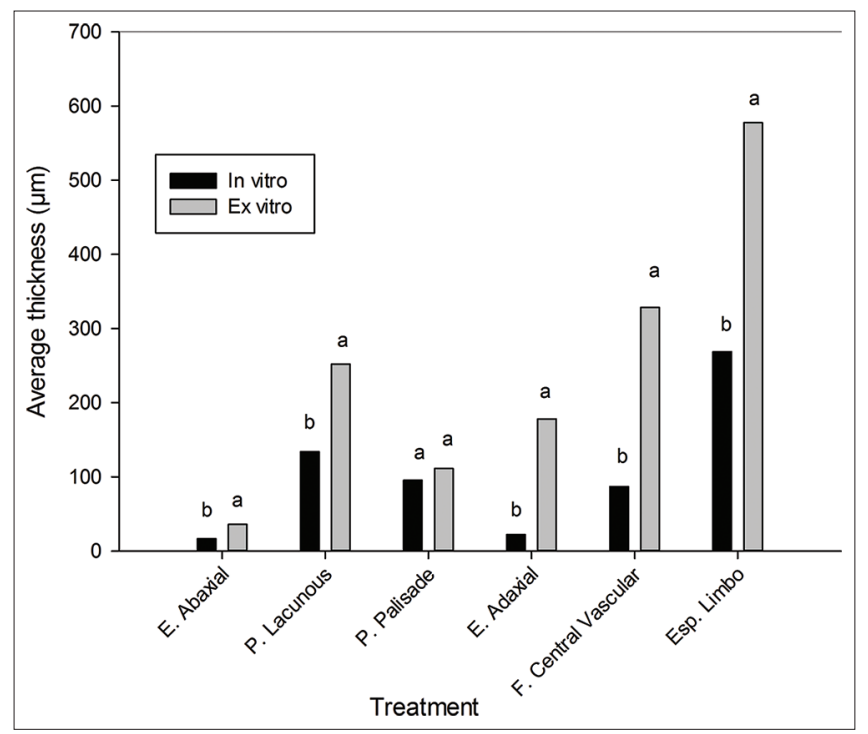

Fig 3. Average thickness $(\mu \mathrm{m})$ of tissues and total thickness of leaf limb of Ginger flower seedlings obtained by in vitro and ex vitro propagation. Averages followed by the same letter in the column do not differ by Scott Knott's test at $5 \%$. T1- leaves of plants at the end of the in vitro rooting phase. Ex vitro plants 60 days after removal of glass.
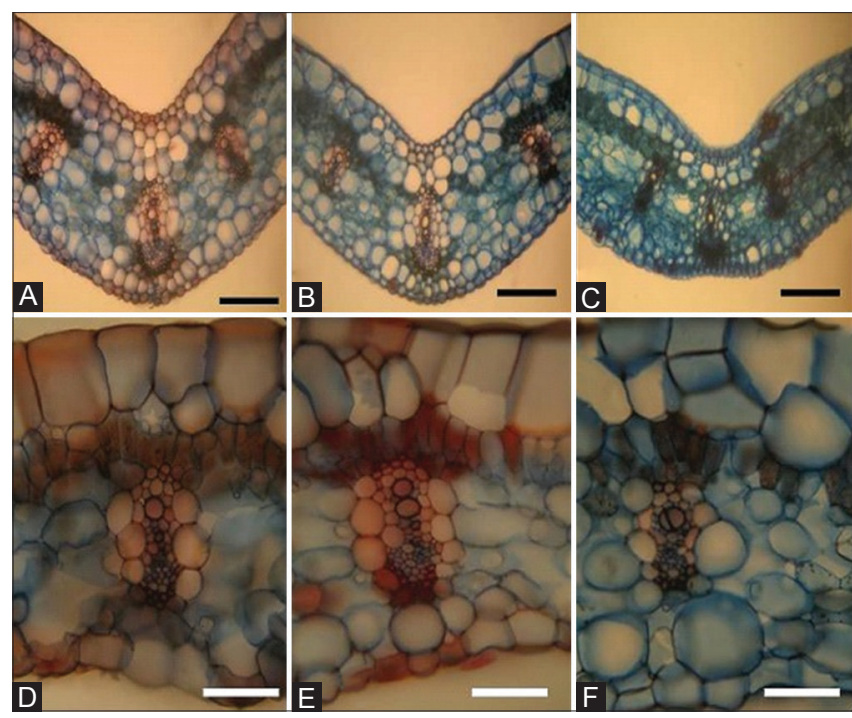

Fig 4. Transversal sections obtained from Ginger flower (Etlingera elatior var. Red Torch) seedlings with 30 days of acclimatization. (A) Central vein of leaves of seedlings irrigated with nutrient solution MS; (B) Central vein of leaves of irrigated seedlings with nutrient solution $\mathrm{HO}$ and $(\mathrm{C})$ Central vein of leaves of seedlings irrigated with nutritive solution BJ. Bars $-50 \mu \mathrm{m}$.

At 30 days of acclimatization, it can be observed that the greatest thickness of limb of Ginger flower leaves was observed in plants grown in nutrient solution MS, followed by plants grown in $\mathrm{HO}$ and BJ (Fig. 5). The thickness of the lacunar parenchyma was the one that most contributed to the greater thickness of the limbo in the plants grown in the MS solution, since no significant differences in the thickness of the epidermis were observed in the three nutrient solutions tested. (Fig. 5). 
In both in vitro and in the acclimatization seedlings, the mesophyll presented a palisade parenchyma consisting of two layers of cells, but these were more elongated in the ex vitro environment. According to Lee et al., (2000), more elongated palisade cells constitute a classical pattern of response and adaptation of plants to high light intensity, which evidences the adaptive plasticity of Ginger flowerplants.

At 45 days of acclimatization, the adaxial and abaxial epidermis develop very rapidly, almost doubling the

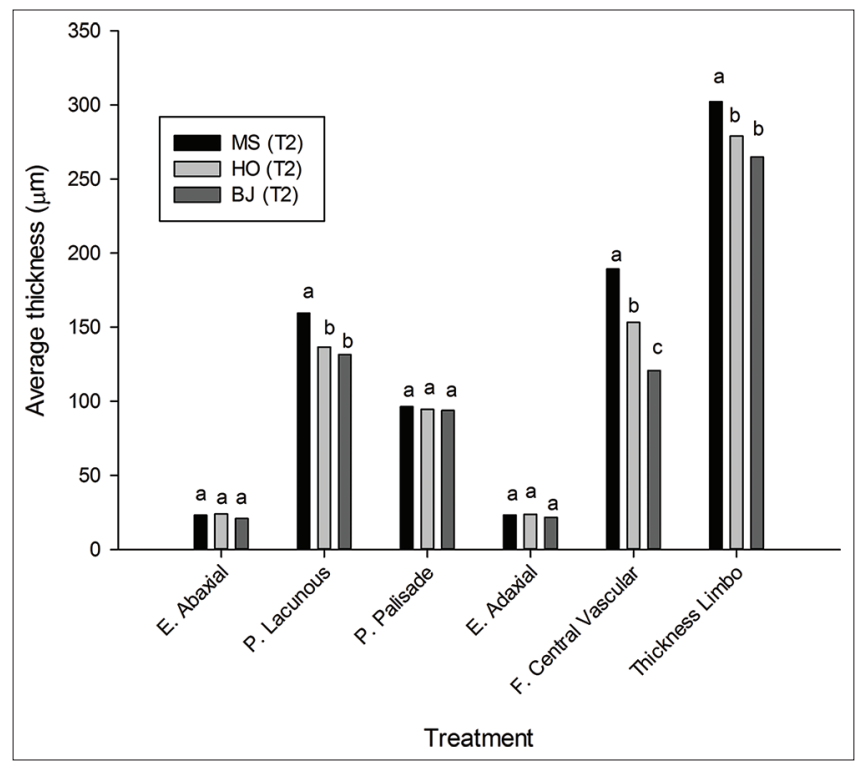

Fig 5. Average thickness $(\mu \mathrm{m})$ of tissues and total thickness of the Ginger flower (Etlingera elatior var. Red Torch), obtained by in vitro propagation and submitted to 3 nutrient solutions, during the first 30 days of acclimatization. Averages followed by the same letter in the column do not differ by Scott Knott's test at 5\%. T2 - persistent leaves (formed in vitro) of plants with 30 days of acclimatization.

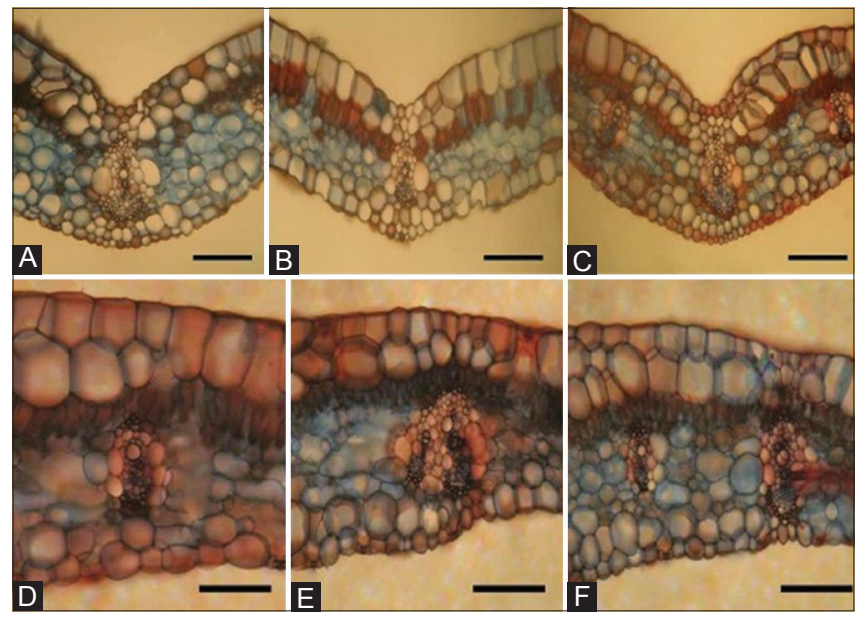

Fig 6. Transversal sections obtained from seedlings of Etlingera elatiorvar. Red Torch, at 45 days of acclimatization. (A) Central leaflet spreading of seedlings irrigated with nutrient solution MS; (B) Central vein of leaves of irrigated seedlings with nutrient solution $\mathrm{HO}$ and $(C)$ Central vein of leaves of seedlings irrigated with nutritive solution BJ. Bars - $50 \mu \mathrm{m}$. thickness, which is a good indicator and shows that the species adapts perfectly to the new culture environment (Figs. 4 and 7).

Nevertheless, the epidermis, once again, do not statistically differ from each other, showing that the solutions are of excellent quality in the acclimatization of Ginger flower seedlings. The differences between the solutions occurred due to the greater thickening of the lacunar parenchyma, increasing in this way a greater thickening of the foliar limb of the irrigated seedlings with MS solution (Fig. 7). The palisade parenchyma presents gradual tissue thickening with the passage of acclimatization time, but it does not differ statistically when compared to the three nutrient solutions used (Fig. 7).

This result corresponds in part to that one reported by Gonçalves et al. (2000) in micropropagated cashew plants (Castanea sativa $\mathrm{x}$ C. crenata), where a progressive increase in the percentage of palisade parenchyma was obtained with acclimatization. However, the leaves formed ex vitro progressively had palisade cells organized, uniform and of more rectangular shape, being the differentiation between the more remarkable parenchyma in the second and third leaves formed during the acclimatization.

At 60 days of acclimatization, the organization of the tissues is in agreement with those observed in the acclimatized plants. The nutrient solution MS was that it more efficiently provided the Ginger flower seedlings with adequate acclimatization, and allowed the correction

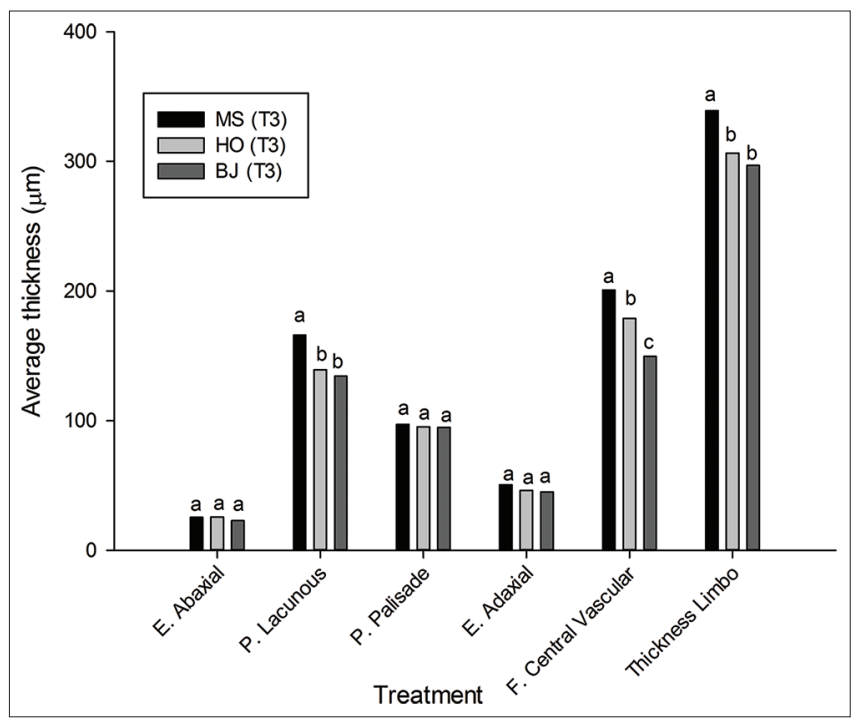

Fig 7. Average thickness $(\mu \mathrm{m})$ of tissues and total thickness of the Ginger flower (Etlingera elatior var. Red Torch), obtained by in vitro propagation and submitted to 3 nutrient solutions, during the first 45 days of acclimatization. Averages followed by the same letter in the column do not differ by Scott Knott's test at 5\%. T3- new leaves formed ex vitro of plants with 45 days of acclimatization (transition leaves). 
of small cell abnormalities caused by in vitro cultivation (Fig. 8).

Greater leaf limb thickness was observed in seedlings irrigated with nutrient solution MS, followed by seedlings cultivated in $\mathrm{HO}$ and BJ (Fig. 9).

The thickness of the lacunar parenchyma was the one that contributed the greatest thickness of the foliar limb of the seedlings grown in nutrient solution MS, since no
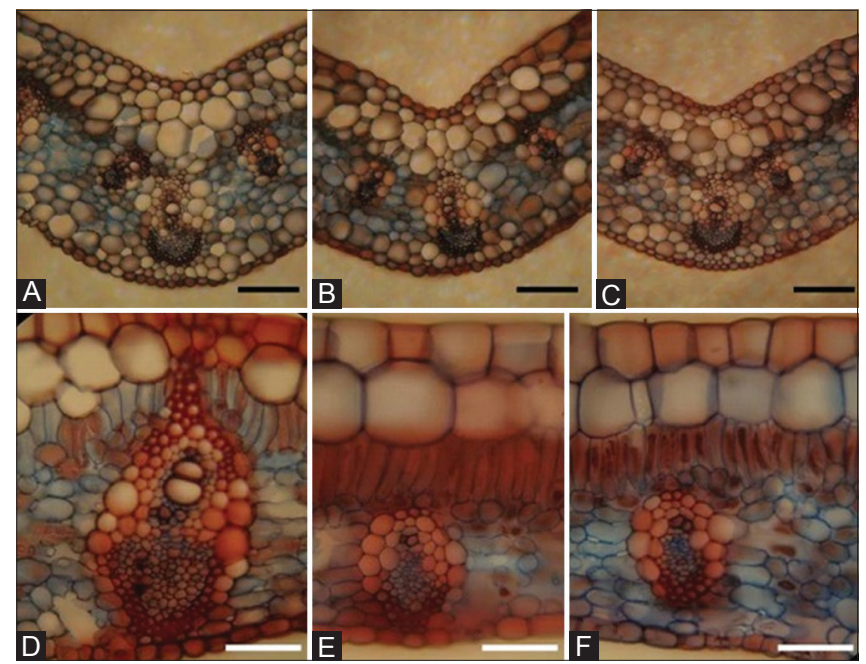

Fig 8. Transversal sections obtained from seedlings of Etlingera elatior var. Red Torch at 60 days of acclimatization. (A) Central vein of leaves of seedlings irrigated with nutrient solution MS; (B). Central spike of leaves of irrigated seedlings with nutritive solution $\mathrm{HO}$ and (C) Central vein of leaves of seedlings irrigated with nutritive solution BJ. Bars - $50 \mu \mathrm{m}$.

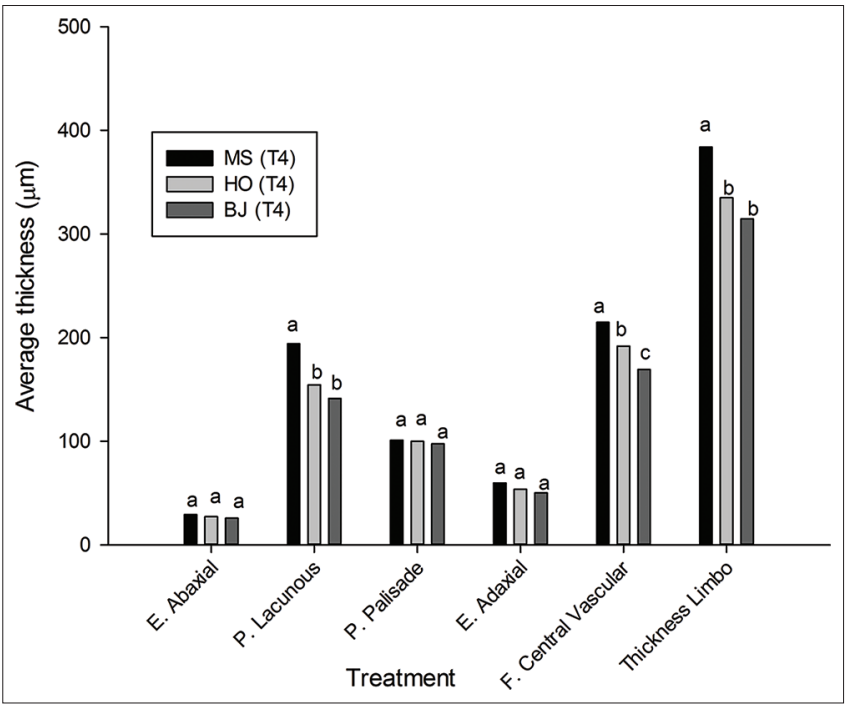

Fig 9. Average thickness $(\mu \mathrm{m})$ of tissues and total thickness of the Ginger flower (Etlingera elatior var. Red Torch), obtained by in vitro propagation and submitted to 3 nutrient solutions, during the first 60 days of acclimatization. Averages followed by the same letter in the column do not differ by Scott Knott's test at 5\%. T4- new leaves formed ex vitro of plants with 60 days of acclimatization (transition leaves). significant differences were observed in the thickness of the palisade parenchyma and epidermis (Fig. 9).

The results observed here show that some anatomical characteristics verified in leaves formed in vitro still persist in the first leaves developed ex vitro and that only leaves originating from ex vitro differentiated foliar primordia have anatomy more similar to the adult plants (in the field), thus agreeing with (Gonçalves et al., 2000; ROMANO; Martins-Loução, 2003). The same authors still argue that the degree of transition and differentiation in relation to the foliar anatomy during the ex vitro adaptation phase of the micropropagated plants is associated to the quantity and stage of maturity of the remaining leaf primordia of the in vitro culture at the moment of the transfer of the plants, as well as the stress conditions in which the plants are submitted.

Regarding the formation and development of the central vascular bundle, the nutritional solution MS is the one that contributes most to a better functionality when compared in all times of evaluation (Fig. 10).

\section{Stomatal density}

The presence of stomata during acclimatization using three different nutrient solutions was only verified in the abaxial epidermis of leaf blades, which characterizes the Ginger flower staff as a hypoestomatic species. There were statistical differences for stomatal density during acclimatization periods (Table 1).

Greater stomatal density was observed in in vitro seedlings (250 stomata per $\mathrm{mm}^{2}$ ) when compared to those ones already acclimatized (60 days) with 190 stomata per $\mathrm{mm}^{2}$, presenting an increase of $76 \%$. The increase in the number of stomata $/ \mathrm{mm}^{2}$ in the leaves of plants grown in vitro, when

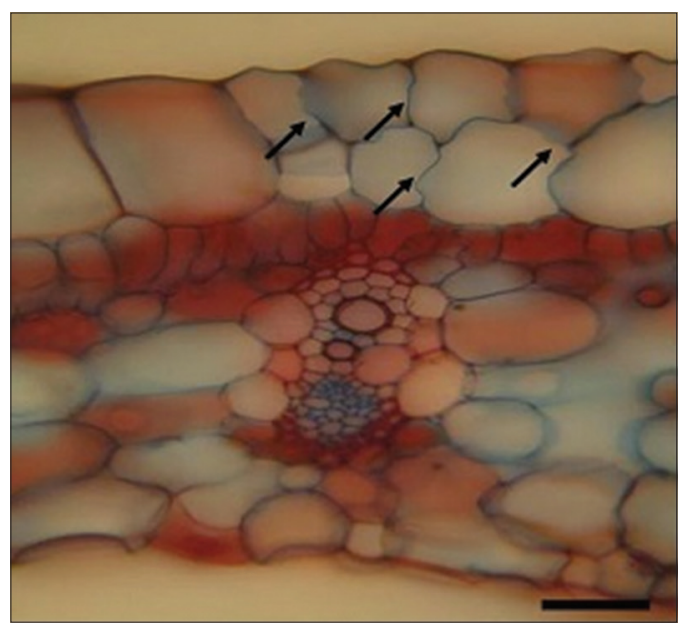

Fig 10. Transversal section of the leaf blade of Etlingera elatior var. Red Torch (Ginger flower) with 30 days of acclimatization presenting

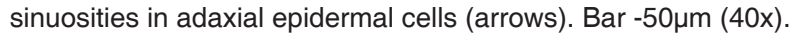


Table 1: Mean number of stomata/mm² (N. stomata), polar diameter (D. polar) and equatorial diameter (equatorial D.) of stomata of the abaxial face in Etlingera elatior var. Red Torch, obtained by in vitro propagation, and submitted to periods of acclimatization with three different nutrient solutions and plants in the field

\begin{tabular}{|c|c|c|c|c|c|c|c|c|c|c|c|}
\hline \multirow[t]{2}{*}{ Parameters } & \multicolumn{2}{|c|}{ Culture Conditions } & \multicolumn{3}{|c|}{ Nutritive Solutions 30 days } & \multicolumn{3}{|c|}{ Nutritive Solutions 45 days } & \multicolumn{3}{|c|}{ Nutritive Solutions 60 days } \\
\hline & In vitro & Ex vitro & MS* & HO* & BJ* & MS** & $\mathrm{HO}^{* *}$ & $\mathbf{B J}^{* *}$ & MS *** & $\mathrm{HO}^{* \star *}$ & $\mathbf{B J}^{* * *}$ \\
\hline N. Stomata $\left(\mathrm{mm}^{2}\right)$ & $250^{\mathrm{a}}$ & $190^{b}$ & $220^{a}$ & $233^{a}$ & $230^{a}$ & $200^{b}$ & $210^{b}$ & $215^{a}$ & $198^{b}$ & $200^{b}$ & $200^{b}$ \\
\hline D. Polar $(\mu \mathrm{m})$ & $60,28^{b}$ & $83,03^{a}$ & $78,45^{\mathrm{a}}$ & $77,61^{a}$ & $77,77^{\mathrm{a}}$ & $79,02^{a}$ & $77,19^{a}$ & $77,26^{a}$ & $77,24^{\mathrm{a}}$ & $79,12^{\mathrm{a}}$ & $79,4^{\mathrm{a}}$ \\
\hline D.Equatorial $(\mu \mathrm{m})$ & $40,09^{b}$ & $45,11^{\mathrm{a}}$ & $42,66^{a}$ & $44,29^{a}$ & $45,22^{a}$ & $45,65^{\mathrm{a}}$ & $45^{\mathrm{a}}$ & $44,74^{a}$ & $45,3^{\mathrm{a}}$ & $45,7^{a}$ & $45,22^{\mathrm{a}}$ \\
\hline $\mathrm{P} / \mathrm{E}$ & $1,50^{\mathrm{b}}$ & $1,84^{a}$ & $1,83^{a}$ & $1,75^{\mathrm{a}}$ & $1,71^{\mathrm{a}}$ & $1,73^{a}$ & $1,71^{\mathrm{a}}$ & $1,72^{\mathrm{a}}$ & $1,70^{\mathrm{a}}$ & $1,73^{a}$ & $1,75^{a}$ \\
\hline
\end{tabular}

Averages followed by the same letter, on the line, do not differ by Scott Knott's test at $5 \% .30{ }^{*}, 45^{* *}$ and $60{ }^{* * *}$ days relate to acclimatization periods

compared to the plants of the same species that grow in other environments, has been reported in several studies associated, mainly, the high relative humidity of the air inside the container under laboratory conditions.

Soares (2005), when studying the acclimatization of mangabeira plants (Hancornia speciosa Gomes), observed that in vitro plants had higher stomatal densities, when compared to the already acclimatized plants. According to Castro et al. (2007), and verified changes in Mikania glomerata Sprengel (Asteraceae), these authors verified that under full sun (field) conditions these leaves had an average of 170 stomata $/ \mathrm{mm}^{2}$ and when they were shaded $30 \%$ the amount of stomata per $\mathrm{mm}^{2}$ increased to 217 .

Quantities, distribution, size, shape and motility of stomata are species-specific characteristics and may change as a function of adaptations to environmental conditions (Larcher, 2000, Camargo, Marenco, 2011). In addition to stomatal behavior, the number and size of epidermal cells can vary significantly between plants grown in different environments (Abrams, Mostoller, 1995). These adaptations of the common and specialized cells of the epidermis are fundamental for the process of adaptation of the plants to different environmental conditions, optimizing, mainly, the process of gas exchanges between the water losses for transpiration and absorption of $\mathrm{CO}_{2}$, necessary for photosynthesis.

According to Goryshina (1989), the stomatal density increases as the radiation intensity is decreased, thus agreeing with the results obtained in this work. The changes in the epidermis are distinct in different species regarding changes in radiation levels. In Ocimum selloi Benth, the frequency and number of stomata in the epidermis in the adaxial and abaxial epidermis were significantly different in plants grown in the field (full solar radiation) and in those ones grown under 50\% shading (Gonçalves, 2001).

For the polar diameter of the stomata, there were significant differences with respect to the environment, which presented larger diameters in the leaves of the plants in the field (Table 1). The stomata of in vitro seedlings of Ginger flower had a polar diameter of $60.28 \mu \mathrm{m}$ and equatorial diameter of $40.09 \mu \mathrm{m}$. In the acclimatized or ex vitro leaves the mean polar diameter of the stomata was $83.00 \mu \mathrm{m}$ and equatorial of $45.11 \mu \mathrm{m}$ (Table 1).

It was also verified that the stomata of the seedlings leaves maintained in vitro presented an oval shape, indicating their inferior functionality in relation to those ones of elliptic form, found in the acclimatized seedlings. Several studies mention that the structure of the stomata of the micropropagated plants present great differences in relation to that one observed in the plants that develop in the natural environment (Fráguas, 2003).

In addition to the stomata, differences in the shape of the epidermal cells were also verified. The cells of the seedling epidermis maintained in vitro are more sinuous and have a less thick wall, which may be related to the fact that these seedlings do not yet present adaptive characteristics against excessive water loss (Fig. 10).

According to Capellades et al. (1990), the period of ex vitro acclimatization allows the reduction in the frequency of the number of stomata changes the format and the topography of these and, in general, favor the several foliar parameters.

\section{CONCLUSIONS}

The foliar structures of seedlings kept in vitro environments present adaxial and abaxial epidermis, as well as a thin thick cuticle. The mesophyll is endowed with a dorsiventral organization, with palisade parenchyma with one or two layers. Stomata are present in large quantities only in the abaxial epidermis, composed of cells of quite sinuous shape. In seedlings of Etlingera elatior var. Red Torch (Ginger flower) already acclimatized, the presence of a bisserial epidermis (adaxial) and uniserial (abaxial), endowed with thick cuticular layer, and is verified. The mesophyll presents dorsiventral organization, with palisade parenchyma constituted of one or two layers of cells quite elongated. The best nutrient solution was MS (Murashige \& Skoog), which was efficient in acclimatizing seedlings of Etlingera 
elatior var. Red Torch (Ginger flower), correcting anomalies caused by in vitro culture.

\section{Contribution of the authors}

Jessé Marques da Silva Júnior Pavão: Part of the dissertation and intellectual mentor.

Evaristo Mauro de Castro: Advisor at the Post-Graduation Program in Plant Physiology - UFLA.

Selenobaldo Alexinaldo Cabral Sant'Anna: Researcher who developed bibliographic research and did the graphics.

Thomé Rodrigues de Pontes Bomfim: Researcher who carried out the translation of the manuscript from the Portuguese language into the English language.

Aldenir Feitosa dos Santos: Researcher who performed the correction of the specific terms of the manuscript.

João Gomes da Costa: Researcher who performed the statistical analysis.

Mayara Andrade Souza: Researcher who performed the adequacy of the manuscript the standards of this renowned journal.

Thiago José Matos Rocha: Researcher who performed the statistical analysis.

\section{REFERENCES}

Abrams, M. D. and S. A. Mostoller. 1995. Gas exchange, leaf structure and nitrogen in contrasting successional tree species growing in open and understores sites during a drought. Tree Physiol. 15: 361-370.

Alquini, Y., C. Bona, M. R. T. Boeger, C. G. Costa and C. F. Barros. 2003. Epiderme. In: G. B. Appezzato and S. M. Carmello-Guerrei (Eds.), Anatomia Vegetal. UFV, Viçosa.

Amancio, S., J. P. Rebordão and M. M. Chaves. 1999. Improvement of acclimatization of micropropagated grapevine: Photosynthetic competence and carbon allocation. Plant Cell Tissue Organ Cult. 58: 31-37.

Anacleto, A., R. R. B. Negrelle, F. L. Cuquel and D. Muraro. 2017. Profile and behavior of flower consumer: Subsidies for marketing actions. Rev Ceres. 64: 557-566.

Bezerra, F. C. and V. Loges. 2005. Zingiberaceae. In: D. Terao, A. C. P. Carvalho and T.C.S. Barroso (Eds.), Flores Tropicais. Embrapa Informações Tecnológicas, Brasília.

Bolle-Jones, E. W. 1954. Cooper its effects on the growth of rubber plant (Hevea brasiliensis). Plant Soil. 10: 150-178.

Bosa, N., E. O. Calvete, A. A. Nienow and M. Suzin. 2003. Enraizamento e aclimatização de plantas micropropagadas de gipsofila. Hortic. Bras. 21: 207-210.

Brained, K. E. and L. H. Fuchigami. 1981. Acclimatization of aseptically cultured apple plants to low relative humidity. J. Am. Soc. Hortic. Sci. 106: 515-518.
Camargo, M. A. B. and R. A. Marenco. 2011. Density, size and distribution of stomata in 35 rainforest tree species in Central Amazonia. Acta Amaz. 41: 205-212.

Castro, E. M., J. E. B. Pinto, A. M. Soares, H. C. Melo, S. K. V. Bertalucci and E. C. L. Júnior. 2007. Adaptações anatômicas de folhas de Mikania glomerata Sprengel (Asteraceae), em três regiões distintas da planta, em diferentes níveis de sombreamento. Rev. Bras. Plant. Med. 9: 8-16.

Campostrini, E. and W. C. Otoni. 1996. Aclimatização de plantas: Abordagens recentes. Embrapa-CNPH, Brasília, p. 12.

Capellades, R., R. Fontarnau, C. Carulla and P. Debergh. 1990. Environment influences anatomy of stomata and epidermal cells in tissue cultured Rosa multiflora. J. Am. Soc. Hortic. Sci. 115: 141-145.

Debergh, P. C. 1991. Aclimatization techniques of plants from in vitro. Acta Hortic. 289: 291-300.

Dunbar-Co, S., M. J. Sporck and L. Sack. 2009. Leaf trait diversification and design in seven rare taxa of the Hawaiian Plantago radiation. Int. J. Plant Sci. 170: 61-75.

Fráguas, C. B., A. R. Pereira and M. Pasqual. 2017. Aclimatização de Plântulas de Ficus carica cv. Roxo-de-Valinhos Micropropagadas. Available from: http://www.ufpel.edu.br/sbfruti/anais_xvii_cbf/ propagacao/928.htm. [Last accessed on 2017 May 27].

Ferreira, D. F. 2015. SISVAR 5.6: Sistema de Análise Estatística. UFLA, DEX, Software, Lavras.

George, E. F. 1996. Plant Propagation by Tissue Culture: Part 2 in Pratice. Exegetics, Edington.

Gonçalves, J. C., G. Diogo, M. T. Coelho and S. Amâncio. 2000. Changes in leaf morphology and anatomy of in vitro-cultured chestnut plantlets during acclimatisation. Acta Hortic. 520: 183-193.

Gonçalves, L. A. 2001. Ontogennia dos Tricomas Glandulares e Influência da Radiação Solar no Desenvolvimento e Teor de Óleo Essencial do Ocimum selloi Benth (Lamiaceae). (Dissertação Mestrado em Botânica). Universidade Federal de Lavras, Lavras.

Goryshina, T. K. 1989. Fotosinteticheskii Aparta Rastenni I Uslovija Sredy. Izd. Leningrad University, Leningrad.

Grattapaglia, D. and M. A. Machado. 1998. Micropropagação. In: A. C. Torres, L. S. Caldas and J. A. Buso (Eds.), Cultura de Tecidos e Transformação Genética de Plantas. Embrapa-SPI/ Embrapa-CNPH, Brasília.

Guan, Q. Z., Y. H. Guo, X. L. Sui, W. Li and Z. X. Zhang. 2008. Changes in photosynthetic capacity and antioxidant enzymatic systems in micropropagated Zingiber officinale plantlets during their acclimation. Photosynthetica. 46: 193.

Guan, Z. J., S. B. Zhang, K. Y. Guan, S. Y. Li and H. Hu. 2011. Leaf anatomical structures of Paphiopedilum and Cypripedium and their adaptive significance. J. Plant Res. 124: 289-298.

Hanba, Y. T., H. Kogami and L. Terashima. 2002. The effects of growth irradiance on leaf anatomy and photosynthesis in Acer species differing in light demand. Plant Cell Environ. 25: 1021-1030.

Hararika, B. N. 2003. Acclimatization of tissue-cultured plants. Curr. Sci. 85: 1704-1712.

Haworth, M. and J. McElwain. (2008) Hot, dry, wet, cold or toxic? Revisiting the ecological significance of leaf and cuticular micromorphology. Paleogeogr. Palaeoclimatol. Paleoecol. 262: 79-90.

Hazarika, B. N. 2006. Morpho-physiological disordens in vitro culture of plants. Sci. Hortic. 108: 105-120.

Hoagland, D. R. and D. I. Arnon. 1950. The Water Culture Method for Growing Plants without Soils. California Agricultural 
Experimental Station, Berkeley.

Johansen, B. A. 1940. Plant Microtechnique. McGraw-Hill Book, New York.

Junqueira, A. H. and M. S. O. Peetz. 2014. O setor produtivo de flores e plantas ornamentais do Brasil, no período de 2008 a 2013: Atualizações, balanços e perspectivas. Rev. Bras. Hortic. Ornam. 20: 115-120.

Junqueira, A. H. and M. S. Peetz. 2017. Brazilian consumption of flowers and ornamental plants: Habits, practices and trends technical article. Ornam. Hortic. 23: 178-184.

Lamhamedi, M. S., H. Chamberland and F. M. Tremblay. 2003. Epidermal transpiration, ultrastructural characteristics and net photosynthesis of white spruce somatic seedlings in response to in vitro acclimatization. Physiol. Plant. 118: 554-561.

Larcher, W. 2000. Ecofisiologia Vegetal. Rima, São Carlos.

Lee, D. W., S. F. Oberbauer, P. Johnson, B. Krishnapilay, M. Mansor, M. Mohamad and S. K. Yap. 2000. Effects so irradiance and spectral quality on leaf structure functions in seedlings of two Southeast Asian Hopea (Dipterocarpaceae) species. Am. J. Bot. 87: 447-455.

Lima-Brito, A., M. M. S. Albuquerque, S. V. Resende, C. E. Carneiro and J. R. F. Santana. 2016. Rustificação in vitro em diferentes ambientes e aclimatização de microplantas de Comanthera mucugensis Giul. subsp. mucugensis. Rev. Ciênc. Agron. 47: 152-161.

Luz, J. M. Q., S. A. Asmar, M. Pasqual, A. G. de Araujo, L. A. S. Pio and R. Ferreira Resende, R. 2012. Modifications in Leaf Anatomy of Banana Plants Cultivar "Maçã" Subjected to Different Silicon Sources in vitro. Acta Horticulturae 961: $7^{\text {th }}$ International Symposium on in vitro Culture and Horticultural Breeding.

Maciel, A. L. R., A. B. Silva and M. Pasqual. 2000. Aclimatização de plantas de violeta (Saintpaulia ionantha Wendl.) obtidas in vitro: Efeitos do substrato. Ciênc. Agrotec. 24: 9-12.

Menezes, N. L., D. C. Silva and G. F. M. Pinna. 2003. Folha. In: B. Appezzato-da-Glória and S. M. Carmello-Guerrei. Anatomia Vegetal. UFV, Viçosa.

Mill, R. R. and D. M. S. Schilling. 2009. Cuticle Micromorphology of Saxegothaea (Podocarpaceae). Bot. J. Linn. Soc. 159: 58-67.

Murashige, T. and F. Skoog. 1962. A revised medium for rapid growth and bioassays with tabacco tissue culture. Physiol. Plant. 15: 473-497.

Neto, C. P. C., F. F. F. Hernandez, F. C. Bezerra, R. F. Sousa and M. F. L. Cavalcante. 2004. Efeito da concentração salina da solução nutritiva na aclimatação de plantas micropropagadas de Violeta Africana (Saintpaulia ionantha Wendl). Rev. Biol. Ciênc. Terra. 4: 1-8.
Neves, M. B., A. A. Watanabe, R. R. Marques, R. N. Fonseca, C. C, Rigolon and C. S. F. Boaro. 2005. Análise de crescimento de girassol ornamental em cultivo hidropônico, com variação de níveis de nutrientes. Bras. J. Plant Physi. 17: 414.

Pandey, S. K., H. Singh and J. S. Singh. 2009. Species and site effects on leaf traits of woody vegetation in a dry tropical environment. Curr. Sci. 96: 1109-1114.

Pospišilová, J., I. Tichá, P. Kadleček, D. Haisel and S. Plzáková. 1999. Acclimation of micropropated plants to ex vitro conditions. Biol. Plant. 42: 481-497.

Romano, A. and M. A. Martins-Loução. 2003. A perda de água e as modificações morphological nas folhas durante o acclimatization do carvalho de cortiça micropropagated plantlets. Acta Hortic. 5: 439-442.

Santos, I. C. F., L. E. M. Oliveira, J. G. Carvalho and A. C. Mesquita. 2005. Aspectos sintomáticos da toxidez de cádmio, níquel e zinco, em diferentes concentrações, para plantas de seringueira [Hevea brasiliensis (Wild. ex. Adr. de Juss.) Muell. Arg.] cultivadas em solução nutritiva. Braz. J. Plant Physiol. 17: 415.

Silva, A. R., N. F. Melo and Yano-Melo, A. M. 2017. Acclimatization of micropropagated plants of Etlingera elatior (Jack) R. M. Sm. inoculated with arbuscular mycorrhizal fungi. S. Afr. J. Bot. 113: $164-169$

Silva, A. B., P. P. Lima, L. E. S. Oliveira and A. L. Moreira. 2014. In vitro growth and leaf anatomy of Cattleya walkeriana (Gardner, 1839) grown in natural ventilation system. Rev. Ceres. 61: 883-890.

Soares, F. P. 2005. Aspecto do cultivo in vitro da mangabeira (Hancornia speciosa Gomes). (Dissertação Mestrado), Universidade Federal de Lavras, Lavras.

Schluter, U., M. Muschak, D. Berger and T. Altmann. 2003. Photosynthetic performance of an Arabidopsis mutant with elevated stomatal density (sdd1-1) under different light regimes. J. Exp. Bot. 54: 867-874.

Unemoto, L. K., R. T. Faria, A. M. Assis, A. B. Lone and L. Y. Yamamoto. 2012. Cultivo de bastão-do-imperador sob diferentes espaçamentos em clima subtropical. Cienc. Rural. 42: 2153-2158.

Van Huylenbroeck, J. M., A. Piqueras and P. C. Debergh. 1998. Photosynthesis and carbon metabolism in leaves formed prior and during ex vitro acclimatization of micropropagated plants. Plant Sci. 134: 21-30.

Vendramini, F., S. Diaz, D. E. Gurvich, P. J. Wilson, K. Thompson and J. G. Hodgson. 2002. Leaf traits as indicators of resource-use strategy in floras with succulent species. New Phytol. 154: 147-157.

Yunus, M. F., M. A. Aziz, M. A. Kadir and A. A. Rashid. 2012. In vitro propagation of Etlingera elatior (Jack) (torch ginger). Sci. Hortic. 135: $145-150$ 